\title{
Streptococcus australis sp. nov., a novel oral streptococcus
}

\author{
${ }^{1}$ Cooperative Research \\ Centre for Eye Research \\ and Technology (CRCERT), \\ University of New South \\ Wales, Sydney, New South \\ Wales 2052, Australia \\ 2 Institute of Dental \\ Research, 2 Chalmers \\ Street, Surry Hills, New \\ South Wales 2010, \\ Australia
}

\author{
M. D. P. Willcox ${ }^{1,2}$ H. Zhu ${ }^{1}$ and K. W. Knox ${ }^{2}$ \\ Author for correspondence: M. D. P. Willcox. Tel: +6129385 7524. Fax: +61293857401. \\ e-mail:m.willcox@cclru.unsw.edu.au
}

\begin{abstract}
Strains of streptococci were isolated from the mouths of children attending the United Dental Hospital, Sydney, Australia. These strains were analysed biochemically using the Rapid ID32 Strep microsystem, were subjected to DNA-DNA hybridization with other members of the oral streptococci and had their 165 rRNA analysed. On the basis of DNA-DNA hybridization, their nearest relative was Streptococcus parasanguinis, whereas, on the basis of 16S rRNA analysis, it was Streptococcus infantis. The name Streptococcus australis sp. nov. is proposed for the new species. The type strain is Al-1 ${ }^{\top}$ ( = ATCC 700641 ${ }^{\top}$ $=$ NCTC $13166^{\top}$ ).
\end{abstract}

Keywords: $\alpha$-haemolytic streptococci, oral cavity, DNA-DNA hybridization, 16S rRNA, Streptococcus mitis group

\section{INTRODUCTION}

The oral cavity is colonized by a large number of different streptococcal species, mostly belonging to the viridans streptococci. Members of the group have been isolated from all areas of the oral cavity, including the tooth surfaces and epithelia. Members of the largest groups of viridans streptococci, containing the species Streptococcus mitis and Streptococcus sanguinis, can colonize all areas of the oral cavity and have been associated with dental caries in animal models (Willcox et al., 1985, 1988) and isolated from cases of endocarditis (Dyson et al., 1999).

It has been notoriously difficult to classify the $S$. mitis group using standard biochemical tests (Ezaki et al., 1988), although tests described by Whiley \& Beighton (1998) have been used successfully. Recently, two species within the $S$. mitis group have been described, namely Streptococcus peroris and Streptococcus infantis (Kawamura et al., 1998). These species were isolated predominantly from the oral cavities/ pharynges of children, some of whom were suffering from Kawasaki disease.

During microbiological analysis of the saliva of children attending the United Dental Hospital in Sydney, Australia, we isolated strains of streptococci that were able to grow on media containing relatively high (up to $500 \mathrm{mM}$ ) concentrations of $\mathrm{NaCl}$ or $\mathrm{KCl}$ (Willcox et $a l ., 1991)$. These strains were initially identified as $S$.

The GenBank accession number for the 16S rRNA sequence (1336 bases) of strain $\mathrm{Al}-1^{\top}$ is $\mathrm{AF} 184974$. mitis (Willcox et al., 1991), but subsequent biochemical analysis and DNA-DNA hybridization (Willcox, 1996) demonstrated that the strains constituted a separate species. From the current study, we present additional data on these strains, including the results of biochemical analyses using the Rapid ID32 Strep microsystem, DNA-DNA hybridization and rRNA gene sequencing.

\section{METHODS}

Bacterial strains and physiological and biochemical analyses. Strains were isolated as described previously (Willcox et al., 1991) on media containing relatively high concentrations of $\mathrm{NaCl}$ or $\mathrm{KCl}$. The strains were routinely grown on Columbia blood (5\%, v/v, defibrinated sheep blood) agar (CBA; Difco) under microaerophilic conditions. Biochemical traits were determined using the Rapid ID32 Strep system (bioMérieux). The ability of strains to grow at $45^{\circ} \mathrm{C}$ was measured in brain/heart infusion (Oxoid) containing $0.3 \%$ $(\mathrm{w} / \mathrm{v})$ yeast extract (BHIY; Difco) and the ability to grow in $6.5 \%(\mathrm{w} / \mathrm{v}) \mathrm{NaCl}$ was tested in BHIY.

DNA-DNA hybridization. DNA-DNA hybridization values were obtained under stringent $(0 \cdot 1 \times \mathrm{SSC})$ or relaxed $(0 \cdot 5 \times$ SSC) conditions as described previously (Willcox, 1996; Kusuda et al., 1991). The type strains used in the DNADNA hybridization were Streptococcus parasanguinis (formerly Streptococcus parasanguis; Trüper \& de'Clari, 1997) ATCC $15912^{\mathrm{T}}$, Streptococcus gordonii ATCC $10558^{\mathrm{T}}$, Streptococcus cristatus (formerly Streptococcus crista; Trüper \& de'Clari, 1997) ATCC $12479^{\mathrm{T}}$, S. sanguinis (formerly Streptococcus sanguis; Trüper \& de'Clari, 1997) NCTC $7863^{\mathrm{T}}$, Streptococcus oralis NCTC $11427^{\mathrm{T}}$ and $S$. mitis NCTC $12261^{\mathrm{T}}$. 
Table 1. Biochemical characteristics of $S$. australis and other members of the viridans streptococci

Data for S. peroris and S. infantis are from Kawamura et al. (1998).

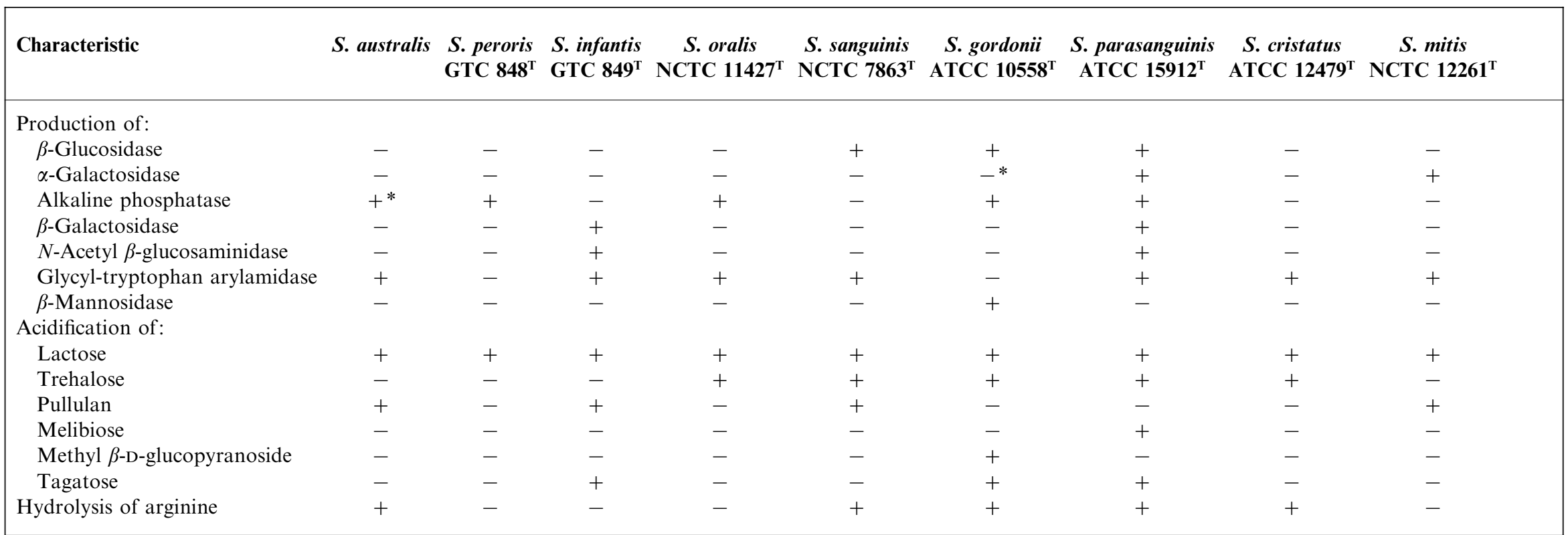

* Opposite reaction in API 20 Strep test kits (Willcox, 1996). 
Table 2. DNA-DNA hybridization values for $S$. australis and other members of the viridans streptococci

Abbreviations: (R), relaxed hybridization conditions; (S), stringent hybridization conditions; ND, not determined.

\begin{tabular}{|c|c|c|c|c|c|c|c|c|c|c|c|}
\hline \multirow[t]{2}{*}{ Strain } & \multicolumn{11}{|c|}{ DNA-DNA hybridization (\%) } \\
\hline & $1(\mathrm{R})$ & $1(\mathrm{~S})$ & $11(\mathrm{R})$ & $11(\mathrm{~S})$ & 12 & 13 & $14 *$ & $15 *$ & $16^{*}$ & $17 *$ & $18 *$ \\
\hline 1. S. australis AI- ${ }^{\mathrm{T}}$ & 100 & 100 & 15 & 7 & 2 & 5 & 10 & 0 & 0 & 0 & 3 \\
\hline 2. S. australis AI-2 & 100 & 100 & 11 & 11 & 0 & 0 & 0 & 0 & 0 & 0 & 4 \\
\hline 3. S. australis AI-3 & 80 & 75 & 11 & 11 & 0 & 0 & 10 & 0 & 5 & 0 & 10 \\
\hline 4. S. australis AI-4 & 100 & 97 & 7 & 2 & 9 & 0 & 0 & 0 & 2 & 0 & 6 \\
\hline 5. S. australis AI-5 & 80 & 79 & 7 & 7 & 7 & 5 & 0 & 0 & 4 & 0 & 8 \\
\hline 6. S. australis AI-6 & 97 & 90 & 33 & 4 & 5 & 0 & 0 & 0 & 4 & 0 & 5 \\
\hline 7. S. australis AI-8 & 80 & 70 & 11 & 11 & 0 & 7 & 0 & 0 & 2 & 0 & 0 \\
\hline 8. S. australis AI-13 & 98 & 98 & 30 & 4 & 2 & 0 & 0 & 0 & 0 & 0 & 4 \\
\hline 9. S. australis AI-15 & 96 & 97 & 19 & 20 & 0 & 0 & 0 & 0 & 5 & 0 & 9 \\
\hline 10. S. australis AI-22 & 98 & 98 & 20 & 4 & 0 & 3 & 0 & 0 & 0 & 0 & 26 \\
\hline 11. S. parasanguinis ATCC $15912^{\mathrm{T}}$ & 53 & 40 & 100 & 100 & 3 & 0 & 13 & 0 & 0 & 21 & 0 \\
\hline 12. S. infantis JCM $10157^{\mathrm{T}}$ & 4 & ND & ND & ND & 100 & 15 & ND & ND & ND & ND & ND \\
\hline 13. S. peroris JCM $10158^{\mathrm{T}}$ & 15 & ND & ND & ND & 23 & 100 & $\mathrm{ND}$ & ND & ND & ND & ND \\
\hline 14. S. cristatus NCTC $12479^{\mathrm{T}}$ & 3 & ND & 1 & ND & ND & $\mathrm{ND}$ & 100 & 0 & 14 & 0 & 0 \\
\hline 15. S. sanguinis NCTC $7863^{\mathrm{T}}$ & 5 & ND & 4 & ND & ND & ND & 20 & 100 & 7 & 0 & 13 \\
\hline 16. S. gordonii ATCC $10558^{\mathrm{T}}$ & 4 & ND & 2 & ND & ND & ND & 0 & 0 & 100 & 25 & 11 \\
\hline 17. S. mitis NCTC $12261^{\mathrm{T}}$ & 5 & ND & 4 & ND & ND & ND & 0 & 0 & 2 & 100 & 91 \\
\hline 18. S. oralis $\mathrm{NCTC} 11427^{\mathrm{T}}$ & 5 & ND & 1 & ND & ND & ND & 0 & 0 & 15 & 45 & 100 \\
\hline
\end{tabular}

* Results from Willcox (1996).

Determination of DNA $\mathbf{G}+\mathbf{C}$ content. Base compositions $(\mathrm{G}+\mathrm{C}$ content) were determined for the proposed new species by the thermal melting method ( $T_{\mathrm{m}} ;$ Johnson, 1981). The $A_{260}$ of the sample was recorded continually while the sample was heated from 50 to $95^{\circ} \mathrm{C}$ in increments of $1.0^{\circ} \mathrm{C} \mathrm{min}^{-1}$. A reference DNA sample from Escherichia coli O157 was prepared.

16S rRNA amplification, sequencing and sequence analysis. The oligonucleotide primers used in this study were synthesized by Auspep (Victoria, Australia). The sequences of the primers corresponded to those within the $16 \mathrm{~S}$ rRNA gene of S. sanguinis (Whiley et al., 1990). The 5' primer 5'CTGGCTCAGGACCAACG-3' corresponded to nucleotides 18-34 of the 16S rRNA and the $3^{\prime}$ primer 5'GCCCGGGAACGTATTCAC-3' corresponded to nucleotides 1375-1392. A PCR was performed in a $100 \mu 1$ reaction containing template DNA (approx. $50 \mathrm{ng}$ ), $2 \mu \mathrm{l} \mathrm{dNTP}$ mix $(10 \mathrm{nM}$ each), $10 \mu \mathrm{l} 10 \times$ reaction buffer [Tris $/ \mathrm{HCl}, \mathrm{KCl}$, $\left.\left(\mathrm{NH}_{4}\right)_{2} \mathrm{SO}_{4}, 3 \mathrm{mM} \mathrm{MgCl} 2, \mathrm{pH} 8 \cdot 7\right], 60$ pmol each primer and $2 \cdot 5 \mathrm{U}$ Taq DNA polymerase (Qiagen). The samples were first denatured for 3 min at $94^{\circ} \mathrm{C}$ and then subjected to 35 cycles of amplification in an FTS-320 thermal cycler (Corbett Research). The parameters for the amplification cycles were denaturation for $1 \mathrm{~min}$ at $94{ }^{\circ} \mathrm{C}$, annealing of primers for $2 \mathrm{~min}$ at $53{ }^{\circ} \mathrm{C}$ and primer extension for $1.5 \mathrm{~min}$ at $72^{\circ} \mathrm{C}$. After the last cycle, the PCR tubes were incubated for $7 \mathrm{~min}$ at $72{ }^{\circ} \mathrm{C}$. On completion, the sample was extracted with 0.6 vols propan-2-ol, precipitated with $2 \cdot 5$ vols ethanol and then resuspended in $20 \mu \mathrm{l}$ distilled water.

The amplified 16S rDNA products were sequenced, using standard dye-terminator chemistry, by the Prince Alfred Macromolecular Analysis Centre, The University of Sydney. The sequences were aligned and the similarity levels were obtained by using the WEBANGIS computer program (Australian National Genomic Information Services). The ECLUSTALW program in WEBANGIS was used to align the sequences. After bootstrap resampling of the alignment, the phylogenetic distances were calculated using the neighbourjoining method (using the algorithm of ENEIGHBOR) and the consensus tree was generated from 100 resulting trees by using the ECONSENSE program in WEBANGIS.

\section{RESULTS}

\section{General characteristics}

After incubation on CBA plates for $3 \mathrm{~d}$, colonies of the novel species were approximately $0.5-1.0 \mathrm{~mm}$ in diameter, rough or raised and white with $\alpha$-haemolysis. The cells were Gram-positive cocci grouped in pairs or short chains. The isolates were catalase-negative, nonspore-forming and non-motile. The strains grew at $45{ }^{\circ} \mathrm{C}$ but not in $6.5 \% \mathrm{NaCl}$ broth.

\section{Biochemical characteristics}

Table 1 demonstrates the biochemical characteristics that differentiate the novel species from closely related species. Strains of all species tested produced alaninephenylalanine-proline arylamidase and acidified media containing lactose, maltose and sucrose. No strain was able to produce $\beta$-glucuronidase, acetoin (VogesProskauer reaction), pyroglutamic acid arylamidase or urease. No strain acidified media containing ribose, mannitol, sorbitol, glycogen, melezitose, L-arabinose 


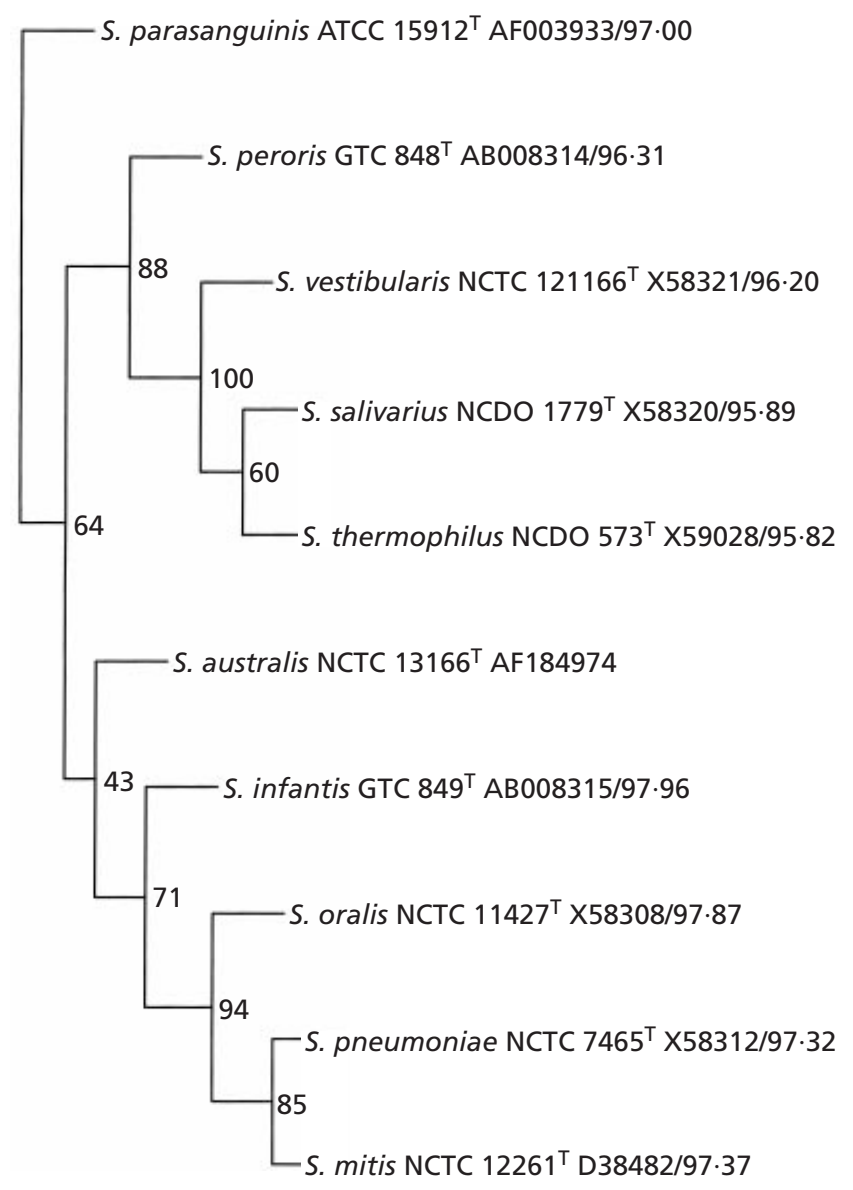

Fig. 1. Unrooted consensus tree showing the phylogenetic position of $S$. australis with respect to selected members of the genus Streptococcus based on 16S rRNA sequences. $S$. parasanguinis was used as the outgroup. The numbers at the branching points are bootstrap values. Strain designations, GenBank accession numbers and $16 \mathrm{~S}$ rRNA similarities (\%) to $S$. australis are listed after species names.

or D-arabinose. Strains were unable to hydrolyse hippurate.

\section{G + C content of DNA and DNA-DNA hybridization}

The $\mathrm{G}+\mathrm{C}$ content of strain $\mathrm{AI}-1^{\mathrm{T}}$ was $43.5 \pm 1 \cdot 2 \mathrm{~mol} \%$. DNA-DNA hybridization studies demonstrated that all strains of the novel species had greater than $79 \%$ homology within the group. The species with the next highest homology was $S$. parasanguinis, showing $40 \%$ homology under stringent conditions (Table 2).

\section{S rRNA analysis}

The 16S rRNA sequence for strain AI- $1^{\mathrm{T}}$ was determined for 1336 bases. An unrooted phylogenetic tree (Fig. 1) demonstrated that the new strain was located in the cluster corresponding to the S. mitis group. The overall similarity to the nearest relative was $97.9 \%$ (to $S$. infantis) (Fig. 1).

\section{DISCUSSION}

The results presented demonstrate that the strains isolated from the saliva of children attending the United Dental Hospital of Sydney should be regarded as a separate species of the oral streptococci, for which we propose the name Streptococcus australis sp. nov. DNA-DNA hybridization studies demonstrated that $S$. parasanguinis has the greatest homology in terms of DNA-DNA hybridization, but this homology only reaches $53 \%$ under non-stringent conditions. Analysis of the $16 \mathrm{~S}$ rRNA demonstrated that the nearest neighbour was a recently described species, $S$. infantis. Both $S$. infantis and $S$. australis form a cluster within the $S$. mitis group, on the basis of $16 \mathrm{~S}$ rRNA similarities. However, the species differ with respect to the production of alkaline phosphatase, $\beta$-galactosidase and $N$-acetyl $\beta$-glucosaminidase, the acidification of tagatose and the hydrolysis of arginine. In addition, the species $S$. australis, $S$. peroris and $S$. infantis were not closely related in DNA-DNA hybridization tests ( $\leqslant 15 \%$ under non-stringent conditions). Of note was the fact that there were nonreciprocal hybridization values between strains $\mathrm{AI}-\mathrm{1}^{\mathrm{T}}$ and ATCC $15912^{\mathrm{T}}$ under stringent and non-stringent conditions. This may have been due to experimental error owing to the use of light emission to measure hybridization; whilst all efforts were made to control it, the timing of the reaction and detection is critical. The technique is robust at the extremes of hybridization, showing close and distant relationships.

Previous results have demonstrated that strains of $S$. australis were able to bind $\alpha$-amylase from human saliva ( $70 \%$ positive) and produce neuraminidase, were unable to react with Lancefield grouping sera and had a peptidoglycan linkage of Lys-Ala-Gly (Willcox, 1996). Using fluorescently labelled synthetic compounds, we demonstrated that $S$. australis was able to produce $\beta$-galactosidase, $N$-acetylglucosaminidase and $N$-acetylgalactosaminidase, but was unable to produce neuraminidase (Willcox et al., 1995). Demonstration of the production of $\beta$-galactosidase and $N$-acetylglucosaminidase with fluorescently labelled substrates was at odds with the results obtained with Rapid ID32 Strep kits, probably demonstrating the effect of different substrates. Indeed, this has been shown previously for different substrates for $\beta$-galactosidase activity (Kawamura et al., 1998). Within the S. mitis group, the species $S$. oralis and $S$. mitis are able to produce glucosyltransferases and $S$. mitis is able to produce fructosyltransferases. However, $S$. australis cannot produce either of these activities (Willcox et al., 1995) and this may be another useful distinguishing characteristic for this species.

Interestingly, both $S$. infantis and $S$. australis were isolated from the mouths of children. In the case of $S$. infantis, the children were between 3 months and 3 years old and many had Kawasaki disease (Kawamura et al., 1998). The children from whom $S$. australis was isolated (from the mouth) were between 8 and 12 years 
old and showed no underlying diseases. Perhaps $S$. infantis and $S$. australis are early colonizers of the oral cavity; the fact that we have never isolated $S$. australis from the mouths of adults (data not shown), together with the absence of reports of $S$. infantis isolated from the mouths of adults, indicates that these species are replaced as part of the oral microbiota over time. Further investigations are needed to determine the habitat and residence time of these streptococci in the mouths of children and adults.

\section{Description of Streptococcus australis sp. nov.}

Streptococcus australis (aus.tra'lis. L. gen. n. australis of the south, southern, relating to the region in which the organism was isolated).

Cells are Gram-positive, non-motile, non-sporulating, catalase-negative cocci. Colonies grow to diameters of approximately $0.5-1.0 \mathrm{~mm}$ on blood agar plates and the cells form short chains. Facultatively anaerobic. $\alpha$ Haemolytic on Columbia blood (sheep) agar plates. The biochemical analysis was performed using Rapid ID32 Strep kits. All strains produced alkaline phosphatase, alanine-phenylalanine-proline arylamidase and glycyl-tryptophan arylamidase, acidified media containing lactose, pullulan, maltose and sucrose and hydrolysed arginine. No strain was able to produce $\beta$ glucosidase, $\beta$-glucuronidase, $\alpha$-galactosidase, acetoin (Voges-Proskauer reaction), pyroglutamic acid arylamidase, $N$-acetyl $\beta$-glucosaminidase, $\beta$-mannosidase or urease. No strain acidified media containing ribose, mannitol, sorbitol, trehalose, raffinose, glycogen, melibiose, melezitose, L-arabinose, D-arabinose, methyl $\beta$-D-glucopyranoside or tagatose. Strains were unable to hydrolyse hippurate. The production of $\beta$ galactosidase was dependent on the substrate used [either 2-naphthyl $\beta$-D-galactopyranoside $(-)$ or $p$ nitrophenyl $\beta$-D-galactopyranoside $(+)]$. Strains have a peptidoglycan linkage type of Lys-Ala-Gly and do not produce neuraminidase (Willcox, 1996). The $\mathrm{G}+\mathrm{C}$ content of the DNA is $43.5 \pm 1.2 \mathrm{~mol} \%$. The strains were isolated from the saliva of humans. The type strain is AI- $1^{\mathrm{T}}\left(=\operatorname{ATCC} 700641^{\mathrm{T}}=\operatorname{NCTC} 13166^{\mathrm{T}}\right)$.

\section{ACKNOWLEDGEMENTS}

This work was partially supported by the Australian Federal Government through the Cooperative Research Centres programme.

\section{REFERENCES}

Dyson, C., Barnes, R. A. \& Harrison, G. A. (1999). Infective endocarditis: an epidemiological review of 128 episodes. $J$ Infect 38, 87-93.

Ezaki, T., Hashimoto, Y., Takeuchi, N., Yamamoto, H., Liu, S. L., Miura, H., Matsui, K. \& Yabuuchi, E. (1988). Simple genetic method to identify viridans group streptococci by colorimetric dot hybridization and fluorometric hybridization in microdilution wells. J Clin Microbiol 26, 1708-1713.

Johnson, J. L. (1981). Genetic characterization. In Manual of Methods for General Bacteriology, pp. 450-472. Edited by P. Gerhardt, K. G. E. Murray, R. N. Costilow, E. W. Nester, W. A. Wood, N. R. Krieg \& G. B. Phillips. Washington, DC: American Society for Microbiology.

Kawamura, Y., Hou, X.-G., Todome, Y., Sultana, F., Hirose, K., Shu, S.-E., Ezaki, T. \& Ohkuni, H. (1998). Streptococcus peroris sp. nov. and Streptococcus infantis sp. nov., new members of the Streptococcus mitis group, isolated from human clinical specimens. Int J Syst Bacteriol 48, 921-927.

Kusuda, R., Kawai, K., Salati, F., Banner, C. R. \& Fryer, J. L. (1991). Enterococcus seriolicida sp. nov., a fish pathogen. Int J Syst Bacteriol 41, 406-409.

Trüper, H. G. \& de' Clari, L. (1997). Taxonomic note: necessary correction of specific epithets formed as substantives (nouns) "in apposition". Int J Syst Bacteriol 47, 908-909.

Whiley, R. A. \& Beighton, D. (1998). Current classification of the oral streptococci. Oral Microbiol Immunol 13, 195-216.

Whiley, R. A., Fraser, H. Y., Douglas, C. W., Hardie, J. M., Williams, A. M. \& Collins, M. D. (1990). Streptococcus parasanguis sp. nov., an atypical viridans Streptococcus from human clinical specimens. FEMS Microbiol Lett 56, 115-121.

Willcox, M. D. P. (1996). Identification and classification of species within the Streptococcus sanguis group. Aust Dent J 41, 107-112.

Willcox, M. D. P., Drucker, D. B., Hillier, V. F. \& Green, R. M. (1985). Relationship of adhesion in vitro and cariogenicity of oral Streptococcus species in germ-free rats. Arch Oral Biol 30, 635-639.

Willcox, M. D. P., Drucker, D. B. \& Hillier, V. F. (1988). In-vitro adherence of oral streptococci in the presence of sucrose and its relationship to cariogenicity in the rat. Arch Oral Biol 33, 109-113.

Willcox, M. D. P., Irwin, A. M., Jacques, N. A. \& Knox, K. W. (1991). Enumeration of oral streptococci on media containing different concentrations of sodium and potassium ions. $J$ Dent Res 70, 1375-1379.

Willcox, M. D. P., Patrikakis, M. \& Knox, K. W. (1995). Degradative enzymes of oral streptococci. Aust Dent J 40, 121-128. 